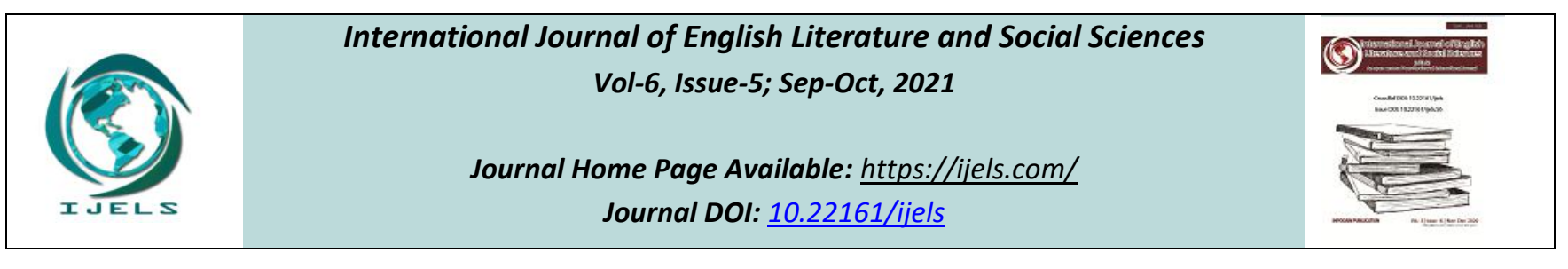

Peer-Reviewed Journal

\title{
A comparative evaluation of Election succeeding tactics in Vikram Chandra's Sacred Games and Chetan Bhagat's Revolution 2020
}

\author{
Ms. Geeta Sharma
}

Assistant Professor, Dept. of English, Eternal University Baru Sahib, Himachal Pradesh, India

Received: 06 Aug 2021; Received in revised form: 05 Sep 2021; Accepted: 13 Sep 2021; Available online: 22 Sep 2021

C2021 The Author(s). Published by Infogain Publication. This is an open access article under the CC BY license

(https://creativecommons.org/licenses/by/4.0/).

\begin{abstract}
The present research paper focuses on election succeeding tactics in Vikram Chandra's Sacred Games and Chetan Bhagat's Revolution 2020. A comparative study of both the writers has been made to reveal the tactics used to win elections in the modern age. Both writers represent the Indian contemporary world through their writings. Chandra has represented through Sacred Games the corrupt and criminal metropolitan city Mumbai. On the other hand, Bhagat gives an overview of Varanasi city through his Revolution 2020. Chandra and Bhagat have represented social evils prevailing in society through their fictional world. In their novels, both authors point out all those despicable issues which make modern contemporary society contemptible. Corruption has been prevailing in every field since immemorial times. The reality of the contemporary corrupt world has been disposed of threadbare through these novels. Political leaders and higher dignities are opportunistic use unethical means to fulfil their ambitions. Sacred Games is the collection of different interconnected stories which make us aware of every aspect of the contemporary world. Various examples have been presented in this novel, which is responsible for changes in society and manners. In Revolution 2020, Bhagat says increasing corruption in society is the outcome of malpractice, crime, political bankruptcy, and sins in the community. Chandra and Bhagat both have revealed the corruption pervaded political departments. These political leaders follow evil ways to come into power. Even they can go to any extent to fuel their ambitions. In these author's opinion, politics is only for criminals only to get success in winning the election. Thus, we see these both authors have given a realistic view of election in their novels.
\end{abstract}

Keywords-Election, corruption, tactics, social evils, bribery, ambitions, contemporary society.

\section{INTRODUCTION}

Vikram Chandra and Chetan Bhagat have presented a realistic election scenario in contemporary society through their novels Sacred Games and Revolution 2020. Both Indian novelists present all those tactics which are being used in modern society for winning the election. It is evident through their study that corruption and crime are prevailing all over the world. Government officers use power to make illegal and private gains. Democracy is demoralized by corruption, and the good governance process becomes inefficient. This corruption creates hurdles on the way of working administration smoothly. To make a nation work smoothly, one needs elections, but the representative doesn't perform their duties honestly. Corruption prevailing in this field has affected the working system of government, which has been revealed realistically by both novelists. Though we see election plays a vital role in democratic governance. A representative is selected from the democracy as a leader who can make them aware and benefit from different beneficial government schemes. Thus, election gives an opportunity to democracy through which they can choose their leaders by making a vote in favor of a good party. 
Through the election, people also get the chance to elect a leader from another party, representing their anger and dissatisfaction for the first party that didn't work well. It is an election through which different issues can be raised in public openly. Ordinary people also can participate in the election to serve the country and to bring reform to society.

Elections in India take place every five years; through this process, political parties review their service and efficiency of work. On the other hand, democracy also gets the opportunity to elect another leader who is best reformative than the previous one. In this way fear of losing their seats and power make the representative do their best. It is only through the election that we check the influence of political leaders. Political leaders can't do the wrong due to the fear of losing power. The same thing has been presented in the novel Revolution 2020 through MLA Shukla's character and in Sacred Games through Bipin Bhonsle. MLA Shukla involves corrupt activities and scams in the 'Ganga Action Plan' project, which Raghav reveals through his newspaper Revolution 2020. Chetan Bhagat's works portray society's reality as his purpose is to portray the social evils and make the public aware by attracting their attention through his novels. Corruption is a social evil that is a significant hurdle on the way of Indian progress and growth. So it should be eradicated, without it our country can't make progress, corruption is growing day by day in all fields, either it should be the field of education, social political or moral, until we eradicate its roots we can't be successful in achieving our aim of a great developed country.

Chandra also presents corruption prevailing in modern society and the role of the underworld in increasing crime in a metropolitan city. He has given a beautiful description of the underworld connection with political leaders and police officers in a pretty realistic manner. This connection is leading criminal activities in modern society. Even the political leader takes help underworld don Ganesh Gaitonde to win the election. The author has also presented many other aspects of the modern city of Mumbai through his novel Sacred Games. Chandra's stories make his readers propel the present to past and past to present, but readers feel firsthand experience. The author makes them realize that everything is happening before them and as they are a part of it. He has used Mumbai city as a character with its slang and narrow streets. Sartaj, a police inspector, has been presented with an honest man whom Gaitonde selected to reveal his secrets before his suicide.

On the contrary, many police officers have been presented indulged in corruption. Through this story, the author wants to message society that those changes that are for the betterment of society should be adopted. Though harmful and retrogressive should be avoided.

Thus, we see Vikram Chandra and Chetan Bhagat have presented the corruption existing in society. People use various tactics to win the election and come into power. They don't think about the progress and development of the country; their purpose is only to earn money. The central government passes various schemes to improve the condition of society, but leaders' scam in these projects. This is the reason why our country is unable to make progress. People who are entitled to the benefits of these schemes don't get the advantage due to corrupt leaders. Chandra presents that such people take help from underworld dons to win the elections because criminal organizations pressurize poor people to caste votes in favor of them.

On the contrary, Bhagat presents big scams made by MLA Shukla with the support of other political leaders. Their planning to win other elections is evident when they prepare Gopal to marry Aarti, whose grandfather has a reputation in society and has been in political power since starting. Shukla wants to stand Gopal as a representative of his party because he will win the election based on Aarti's family if he gets married to her. In this way, it's evident that both these writers have revealed contemporary election-winning tactics through their works.

\section{PURPOSE OF STUDY}

The objective of the present research article is to reveal the election succeeding tactics which, have been exposed in Vikram Chandra's Sacred Games and Chetan Bhagat's Revolution 2020. Both authors present electionwinning tricks from their point of view, which are in practice in contemporary society. Chandra explains that political leaders take underworld don's help to succeed in election. On the other hand, Bhagat unfolds that how political leaders bring out a clear image representative to participate in the election from their side. Political leaders aim only to come in power by using different tricks instead of serving the country honestly. In this way, corruption has been portrayed by these authors which, is occurring in the election sector in contemporary society. Saviors of society are indulged in corrupt tricks then how we can imagine a corruption free country. To work a system well, corruption must be removed from society.

\section{RESEARCH METHODOLOGY}

This present research paper is based on the qualitative perspectives of the content analyzing process, which is also called the procedure of summarizing various types of 
text and content matter in the field of literature. Different observations are made on a literary text, which persuades a more objective appraisal of content instead of impressing the audience. Though exploring content can be in any shape and form, it has been converted into written form before analyzing it. This research is based on Vikram Chandra and Chetan Bhagat's novel Sacred Games and Revolution 2020. The objective of the present research paper is to establish a connection between cause and effect. The paper researcher throws light on the election succeeding tactics taking place in modern society through this research. The political representative can go to any extent to win the election. The researcher made a genuine effort through this article to trail the reality of society and explore all the tactics modern people use to win the election. The researcher has used the qualitative analyzing method at the time of analyzing content for reaching on conclusion. Quotations and passages used in this research article have been taken from the primary source and observed critically. The quotes or material taken from primary sources, directly or indirectly, have been supplemented by the information from secondary sources. The research articles from various renowned critics and scholars also have been used to substantiate this article. To prove the point, matter also has been taken from online resources. Along with primary sources, different online and offline resources have been explored to complete this research article and conclude.

\section{RESULT}

\section{Exposure of election succeeding Tactics in Sacred Games and Revolution 2020}

Vikram Chandra has portrayed the reality of modern society through his novel Sacred Games. He has given a very beautiful description of election succeeding tricks in this novel. The story of this novel reveals various secrets of society before us. In the modern age, the main motive of political leaders is only to come in power and earn money. They can go to any extent for coming in power ethics have no value for them. In politics, the public favors those who have money; election takes a lot of money. Bipin Bhonsle was a candidate from Rakshak dal. He was sure for the vote from the Marathas of the office workers and class 2nd government officers and clerks. He was the pockets of Gujrati and Marwari shopkeepers and traders scattered here. His problem was the other half Congress voters and the RPI diehards, who live in the Narayan housing colony and around Satya Sagar estates and in the basti's of Gandhi Nagar and Lalghar. This is the reason why the Rakshak party had never been able to win the election in Marwada.
These all were all sorts of seths and professionals, airline crew and Rotaries.

On the other hand, Lal Garh was a Muslim Basti, so there was no vote for Rakshak. Bipin Bhonsle came to meet Gaitonde to help him in this work because when his men went to canvass, other party members pushed around some of their people and grabbed posters from them. They took two bundles, and fifty posters made a bonfire out of them. This is why he is there to help Bipin Bhonsle also says to Gaitonde when the whole world is dirty, and you will have to go dirty to do any cleaning, to fight with their money. He will have to use tricks once he is in power. Everything will get changed. Gaitonde inquiries about the Rakshak party; why didn't they protest the other party when they were grabbing their posters and making a bonfire. Bipin Bhonsle response that all the boys in the party were strong muscles, so they couldn't oppose them. He requests Gaitonde to help him win the election because he is ready to give any amount of money. Gaitonde gets prepared to help Bipin Bhonsle, but there is a dealing of thirty lakh rupees between them because he needs to provide twentyfive or thirty thousand rupees to each boy. Gaitonde makes him realize that he will win democracy by spending thirty lakh rupees. Thus, a deal is made final between Bipin Bhonsle and Gaitonde for winning the election.

Gaitonde starts working on election succeeding tactics from the next day. His men accompany Rakshak dal, and they put their campaign into every nook, which was appealing to the voters from a distance. His two boys were armed with pistols to make Rakshak's do their work peacefully. Gaitonde works hard with his men to get Bipin Bhonsle success. It is observed on the final day of the election that Bipin Bhonsle was significantly disturbed about the result of the election for which he had spent an enormous amount of money. Congress party's men were going in Muslim bastis and their homes because they were using the trick to win the election. On meeting every man, they were giving him one hundred rupees note and a bottle of rum with good fresh mutton, because in this bastis this is the basis of succeeding in the election. A poor man drinks peg, fills his stomach with good food, and rides on his wife for voting; finally, both go for the voting booth happily. This delicious food makes them forget everything about politicians' speeches, robbery, murders, and country development. These poor, illiterate people castes vote based on food and wine. In this way, these corrupt representatives become successful in gaining power and serve the country without roti kapda and makaan. Thus, political leaders feed sheep to sheep to herd them in the direction towards the slaughterhouse. Gaitonde observes these modern tricks used for winning the election. He also made a scheme to get Bipin Bhonsle to win the election. 
His tactics were that he sent his boys to market, bazaars, restaurants RPI and Congress areas to spread rumours that goondas are coming on the election day. This rumour is spread for two days before the election; for this, they hire thugs.

According to Gaitonde, rumour is the best weapon to demotivate the people, and it starts from zero, then it grows and mutates with speed. He gets ready thirty motorcycles and removed their license plates removed. Two boys were riding on each bike by covering their faces by dacoit's scarves. They had soda bottles bags for the pillion riders. These forty bikes went through opponent party areas with hooting and roaring. They shook the bottles and broking, making burst sound enough to make few brave citizens scared and trembling. After, this incident police reached there with their rifles and lathis. Inspector Samant was also with them, who made a phone call to Gaitonde and informed him about DCP Saab and ACP Saab. He reports that all are patrolling to stop any disturbance. There is no one on the road, only three dogs; this information brings a smile to Gaitonde's face. Bipin Bhonsle had paid the whole police department to maintain the peace. Condition is now in favor of Gaitonde because now the enemy will stay at their home, so no booth capturing and ballot stuffing will occur. Thus, in peaceful ambience all his boys spread all over the area and started taking the voters towards the booths. They convinced the voters that they were members of the election committee for a fair election. Bipin Bhonsle was smiling with his men seeing these tactics, but Gaitonde's boys left the voters alone when they filed in, they made their little mark on the ballot, and the folded paper fell into the slotted wooden boxes. In the evening, all the boys returned to Gopalmath, where Gaitonde distributed them money for their work. Bipin Bhonsle wins the election and comes to meet Gaitonde and to thank him with different kinds of sweets, a Video player, and many other gifts. In this way, Gaitonde's election succeeding tactics favor Bipin Bhonsle in gaining power.

On the other hand, Chetan Bhagat also describes electionwinning tricks in his novel Revolution 2020. The story of this novel revolves around Gopal, Aarti, and Raghav, three childhood classmates. Gopal belongs to a low-income family, his father wants to make him an engineer, but he doesn't focus on his study and wastes his time in the company of his friends. His father loves him very much, but no compromise when there is a matter of career. His father decides to send him Kota for coaching though Gopal wants to get admission in his hometown. Gopal couldn't clear the exam for IIT or JEE despite pursuing coaching from Kota. His father couldn't bear the shock of his son's failure, which resulted in death. Gopal falls in love with
Aarti, who is the daughter of the district magistrate and granddaughter of the former MLA of the constituency. Gopal comes in contact with MLA Shukla. He is only the twelfth pass, but with the help of M.L.A, Shukla becomes the director of an engineering college constructed on his disputed land. His friend Raghav after completing his degree, starts to work as a reporter in "Danik'. He is sincere who starts to unveil M.L.A Shukla's Ganga Action Plan scams worth twenty crores through Danik newspaper. The reputation of Shukla's Ganga Tech college comes down after this revelation, he gets Raghav sacked from the newspaper, but Raghav faces it boldly and starts his own newspaper, Revolution 2020.

He works hard to publish an article about the Ganges treatment scam and proves that Shukla is corrupt. Thus, Raghav is successful in getting him forced to resign. MLA Shukla a corrupt local political leader of Varanasi. In a surprising affirmation to CNN-IBN special investigation squad, Vijay Panjwani, a legal counsel to the central pollution control board, found out that the Ganga river remains polluted even after spending Rs 20,000 crore to clean that up. Shukla seized a massive amount of money in Ganga Action Plan, leaving behind him no evidence besides it. He tries to use that money in some good ways by opening a college. Thus, due to corruption, GAP has not been implemented for ages, and there have not been effective results. Through this novel, Bhagat wants to deliver a message to society that they should be aware of corrupt people like MLA Shukla, who is sucking the blood of the country. Raghav wrote his first article on the corruption of 20 crores rupees which was for the Ganga Action Plan for cleaning the river, without collecting any proof against MLA Shukla, but later became successful in proving it by citing all the proofs of how MLA managed to dump the dirty water elsewhere, in the river and claim to have cleaned it. The article gives a picture of the Varuna river with the dot where he released effluents; this article creates trouble for MLA by exposing his fake invoice, his link with the contractor, and the audacity of dumping the dirty water again into the Ganga river.

Raghav's article attracts the attention of the entire mainstream newspaper and new's channel. In an interview with a news channel, he proves MLA Shukla corrupt by presenting all the pieces of evidence against him. The image of an ideal youth has been presented through the character of Raghav, a person who can't be bought and threatened.

On the other hand, we see CM's reaction after the MLA exposition before the public; CM asks Shukla to resign from his position. He said to Shukla though we are friends, but the party is above friendship; 
"The CM is a behenchod, he said. I kept quiet. When he needed his election fundings, he came to me. I did his dirty work, distributing liquor all over the state. Now he screws me; you will come out of it, Shukla-ji, you always do." Nobody gives a fJik about cleaning the Ganga. Everyone made money on that plan so why me?" (Bhagat p-241)

Though CM is also involved in this corruption, how he makes himself accessible by saying it, Shukla Ji, why did you not make a plant it does not matter how much percent spends here and there, but how you can think showing dirty water into Varuna Ganga. People consider it mother Ganga, and they will kill us if they come to know about reality. Besides it we have an election next year, always we are respected and win without interference, but this time it will take us down. Thus, we see Shukla is expelled from his seat by CM. In this way, we see CM is preparing for the next coming election. He has removed Shukla Ji from his seat to make clear his image in front of the public to win the coming election. On the other hand, we know that Gopal is forced to marry Aarti by Shukla because she is the granddaughter of a former Congress party leader. Her grandfather was a very prestigious leader, so Shukla wants Gopal to participate as a representative of their party. All people from Varanasi will vote them on the name of Aarti's grandfather. Thus, Shukla and CM both use their tricks to come into power. It is evident through the study of Vikram Chandra and Chetan Bhagat that both have given a realistic description of election succeeding tactics in their novels. These tactics are being used by modern contemporary society to win power and money.

\section{DISCUSSION}

Thus, the present study clearly shows that Vikram Chandra and Chetan Bhagat have used the election succeeding tactics in their novels Sacred Games and Revolution 2020. In the modern age, corruption is prevailing in all spheres of life. Political leaders are after materialistic gains and luxuries. They spend a lot of money to take the election in their favor. Their purpose is only to earn money and gain power, not the welfare of the country. They seduce the voters in the name of liquor and good food, but after taking the vote, they forget about them. This type of mentality of our political leaders is an obstacle to the progress of the country. Youth have to remove this flaw if they want a developed country. In the words of Raju (2015), "money power influence is also a major defect in our electoral system. Now a day's elections are costly affair where votes are being like a market goods through buying and selling." According to Pradeepa \& Priya (2020) "corruption demoralizes democracy and better governance subverting formal process in politics."
Honmode says (2019) "Sacred Games deals with the aspect of the portrayal of gendered politics, women, patriarchy, communal violence, gangsters, politicians, mafia, businessmen and the Mumbai police." Rao reveals (2015) "Chandra has interwoven in his novel Sacred Games love, crime, corruption, politics, police, betrayal and beauty in a realistic manner."

In the same way, Chetan Bhagat has presented the election-winning tactics and corruption prevailing in the society in Revolution 2020. In the words of Babu \& Livingston (2019), "this novel discusses in detail about how the Indian government aids in corruption." On the other hand, Sharma says (2015), "in modern age corruption has changed the motive of posts. Higher posts are the symbol of dignity, reputation and responsibilities but in modern age are only medium of personal gains." According to Wankhade (2015), "Chetan Bhagat as a skilled craftsman reaches to the heart of the young readers, which is the largest asset of the world." According to Raviya (2017), "Chetan Bhagat depicts and portrays the youth and their concerns about modern society." In the words of Kulkarni (2016), "Chetan Bhagat delivers message if we want to bring revolution we have to contribute."

\section{CONCLUSION}

The study of both Vikram Chandra and Chetan Bhagat concludes that they have portrayed the election succeeding tactics in quite a realistic manner. In his Sacred Games, Chandra reveals how Bipin Bhonsle takes help from underworld don Ganesh Gaitonde to win the election. He spends a lot of money on the election. Based on money, Bipin Bhonsle wins the election; for it, he spends thirtyfive lakhs. Gaitonde creates terror among ordinary people that goondas are arriving on the day of the election. To make them scared, he goes to the basti with forty bikes and eighty boys hooting and breaking bottles of sodas. This event raised terror in the mind of voters. The police are also bribed by him, which reveals corruption prevailing in society.

On the other hand, rivalry party of Bipin Bhonsle distributes liquor and delicious food among poor residents of basti. These political representatives don't think about the development of the country and roti kapda or makan of poor people. They only think about themselves, for it they can go to any extent. Corruption prevailing in the police department and political field is the root cause of the country's backwardness. In the same way, Bhagat has also given a beautiful description of election gaining tricks through the character of CM; the author has presented the corruption prevailing in the political field. However, CM 
himself is also involved in the GAP project scam but expel MLA Shukla from his party to present a clear image of his party before the public. CM uses a trick to save his post and party, for which Shukla abuses him and exposes all his wrongdoings in front of Gopal. CM reserves his chair; on the other side, Shukla plans to establish his separate party. He insists Gopal marry Aarti to stand in the election on the name of his grandfather's reputed image. Thus, through Sacred Games and Revolution 2020 these authors have presented the basic inception of corruption and election succeeding tricks used by opportunistic leaders. We see in the modern age; corruption has changed the meaning and purpose of posts. Though political leaders are considered a symbol of dignity, welfare, and responsibilities, this post is now achieved only for power and luxuries. Political leaders have not concerned with the development of the country, and they only want money. This study proves Chandra and Bhagat have presented a beautiful election scenario of contemporary society through their novels.

\section{REFERENCES}

[1] Babu, R and Livingston, $T$ (2019) Societal evils in contemporary India from Chetan Bhagat's perspectives in Revolution 2020. International Journal of Recent Technology and Engineering, 8(1) pp-1074-1075.

[2] Chandra, V (2006) Sacred Games. New Delhi: Penguin.

[3] Honmode, S (2019) Understanding the Indian web series an analysis of Sacred Games. Journal of Emerging Technologies and Innovative Research, 6(6) pp 258-266.

[4] Kulkarni, D S (2016) Social realism: representation of problems of youth and fraudulent society in Chetan Bhagat's Revolution 2020.An International Journal of Interdisciplinary Studies, 1(2) pp-1-5.

[5] Pradeepa, M and Priya, M (2020) Multi-faceted Indian cosmopolitanism in Vikram Chandra's Sacred Games. International Journal of engineering applied sciences and technology, 4(9) pp 173-175.

[6] Raju, B (2015) Indian electoral system- major issues and remedies. Paripex: Indian Journal of Research, 4 (11) pp 28-30

[7] Rao, N V (2015) Unfurling the crime and glamour in Vikram Chandra's Sacred Games the detective fiction. International Journal of English Language, Literature and translation studies, 2(3) pp 49-52.

[8] Raviya, H D (2017) Representation of modern milieu in Chetan Bhagat's 2020 Revolution. Galaxy: International Multidisciplinary Research Journal, 8(1) pp-1184-1194.

[9] Sharma, A K (2015) Corruption in education system in Chetan Bhagat's Revolution 2020, love, ambition, corruption. International Journal on studies in English Language and Literature, 3(1) pp -30-34.

[10] Wankhade, B (2015) Codification of adults and adultery in Revolution 2020 of Chetan Bhagat. Global Journal for Research analysis, 4(2) pp-82-83. 